\begin{tabular}{|c|l|}
\hline Title & $\begin{array}{l}\text { Genetic divergence and population structure of black sea bream A canthopagrus schlegeli inferred from microsatellite } \\
\text { analysis }\end{array}$ \\
\hline Author(s) & $\begin{array}{l}\text { Jeong, Dal-Sang; U mino, Tetsuya; Kuroda, Kenji; Hay ashi, Marehiko; Nakagawa, Heisuke; Kang, Ju-Chan; } \\
\text { Morishima, Kagay aki; A rai, Katsutoshi }\end{array}$ \\
\hline Citation & $\begin{array}{l}\text { Fisheries Science, 69(5), 896-902 } \\
\text { https://doi.org/10.1046j.1444.2906.2003.00705.x }\end{array}$ \\
\hline Issue Date & 2003 \\
\hline Doc URL & http://hdl.handle.net/2115/35206 \\
\hline Rights & ○ 2003 公益社団法人日本水産学会; @ 2003 The Japanese Society of Fisheries Science \\
\hline Type & article \\
\hline File Information & arai-79.pdf \\
\hline
\end{tabular}

Instructions for use 


\title{
Genetic divergence and population structure of black sea bream Acanthopagrus schlegeli inferred from microsatellite analysis
}

\author{
Dal-Sang JEONG, ${ }^{1}$ Tetsuya UMINO, ${ }^{1 *}$ Kenji KURODA, ${ }^{1}$ Marehiko HAYASHI, ${ }^{1}$ \\ HeIsuke NAKAGAWA, ${ }^{1}$ Ju-Chan KANG, ${ }^{2}$ KagaYaKi MORISHIMA ${ }^{3}$ AND KaTSuTOSHi ARAI ${ }^{3}$ \\ ${ }^{1}$ Graduate School of Biosphere Sciences, Hiroshima University, Higashi-hiroshima, Hiroshima \\ 739-8528, ${ }^{3}$ Graduate School of Fisheries Sciences, Hokkaido University, Hakodate, Hokkaido \\ 041-8611, Japan and ${ }^{2}$ Department of Aquatic Life Medicine, Pukyong National University, \\ Daeyon 599-1, Namgu, Pusan 608-737, Korea
}

\begin{abstract}
Four highly variable microsatellite loci, Acs $1^{\star}, A \operatorname{cs} 3^{\star}, A c s 4^{\star}$ and $A \operatorname{cs} 9^{\star}$, were isolated and then used to investigate genetic diversity and population structure in black sea bream, Acanthopagrus schlegeli, collected from wild populations of six locations (western Japan and southern Korea), and hatchery stock and post-stock populations from Hiroshima Bay. When allelic segregation of each microsatellite locus was examined using the single spawning pair and their progeny, all loci were well fitted to the Mendelian manner of inheritance. The genetic variations at these loci in the eight populations revealed high levels of variability. In the wild populations the mean number of alleles per locus was 10.8-13.5, and the mean observed hetrozygosity was $0.755-0.828$. In contrast, these values in hatchery stock population were 10.0 and 0.776 , respectively. Genetic distance indicates the existence of geographic divergence between western Japan and south Korea, and little genetic differentiation among populations in western Japan.
\end{abstract}

KEY WORDS: Acanthopagrus schlegeli, black sea bream, genetic variability, Mendelian inheritance, microsatellite, population structure.

\section{INTRODUCTION}

The understanding of genetic divergence and diversity is one of the most important steps in managing fishery resources. A large number of artificially produced offspring have been released into the natural environment for stock enhancement without considering the influence on genetic structure. The broodstocks for seed production have a small gene pool, so the stocked offspring will cause a fluctuation in gene frequencies as well as the decrease of genetic polymorphisms in the wild. ${ }^{1,2}$ Tessier et al. ${ }^{3}$ have reported an extreme case in which stocked offspring caused major genetic drift and a $50 \%$ reduction in effective population size of a wild Atlantic salmon population. Therefore the stocking projects should be done with better understanding of genetic variation and divergence.

*Corresponding author: Tel: 81-824-24-7944.

Fax: 81-824-22-7059. Email: umino@hiroshima-u.ac.jp

Received 22 July 2002. Accepted 24 March 2003.
Microsatellite markers, tandem arrays of di-, trior tetra- nucleotide sequences flanked by regions of unique DNA sequences, ${ }^{4,5}$ have proved to be a powerful tool for the assessment of genetic divergence and diversity of many fish. ${ }^{6-12}$ Several studies have used microsatellite DNA markers to study the genetic variability of artificially stockèd seedlings. For example, studies have been conducted in amberjack, ${ }^{9}$ Japanese flounder ${ }^{10}$ and red sea bream. ${ }^{12}$

In Japan, black sea bream, Acanthopagrus schlegeli are an important commercial fisheries resource and are popular in sport fishing. The total amount, which exceeded 6 million, was stocked in 2001. Several researchers have tried to determine the fish quality and survival rates of this stocking seed. ${ }^{13-15}$ However, they could not determine the stock efficiency because of problems in tagging the stocked fish. Therefore highly sensitive genetic markers, such as microsatellite DNA, should be provided as a powerful tool.

The objective of the present paper is to report the isolation and characterization of microsatellite 
loci in wild black sea bream from western Japan and Korea. Using these loci, levels of genetic divergence and variation were surveyed in the stocking seed.

\section{MATERIALS AND METHODS}

\section{Hatchery stocked samples}

Hatchery-stocked black sea bream were produced by the Hiroshima City Marine Products Promotion Association in 1997. They produced 51 broodstock, composed of 29 female and 22 male fish. When the fertilized egg production reached its peak in May, the eggs were collected for 1 day and transferred to a rearing tank. After 2 months' rearing the hatchery stock population was collected prior to release.

A total of 20000 hatchery stock black sea bream with a mean total length of $4.0 \mathrm{~cm}$, was released into Daio Bay of Nino-shima Island, Hiroshima Bay $^{13}$ where stock enhancement projects have been carried out since 1979. The samples of poststock population were collected 10 days after stocking at the release point. According to the previous study, these samples might be composed of $50 \%$ hatchery stock and $50 \%$ indigenous recruiters. $^{13}$

\section{Wild samples}

Before the stocking was carried out at Daio Bay of Nino-shima Island, indigenous recruiters were collected by a throwing net as a wild population at Hiroshima (Hiroshima pupulation). Other wild populations in western Japan, Kochi (Susaki city, Uchinoura Bay), Mie (Watarai gun, Gokasho Bay), Nagasaki (Konagai city, Isahaya Bay) and Tottori (Sakaiminato city, Miho Bay), were sampled by angling in 2000. These samples ranged from 14.9 to $48.0 \mathrm{~cm}$ in body length. Wild population were also collected from Yosu city, in southern Korea, in 1999. Because Korea has not performed stock enhancement frequently, the Yosu samples will be a useful control when comparing frequently stocked populations in Japan. Sampling locations in the present study are shown in Fig. 1. Fifty fish were sampled from each location except Nagasaki $(n=27)$.

\section{Microsatellite analysis}

The DNA extraction from muscle tissue was carried out by the standard sodium dodecylsulfate (SDS)-phenol/chloroform procedure. The

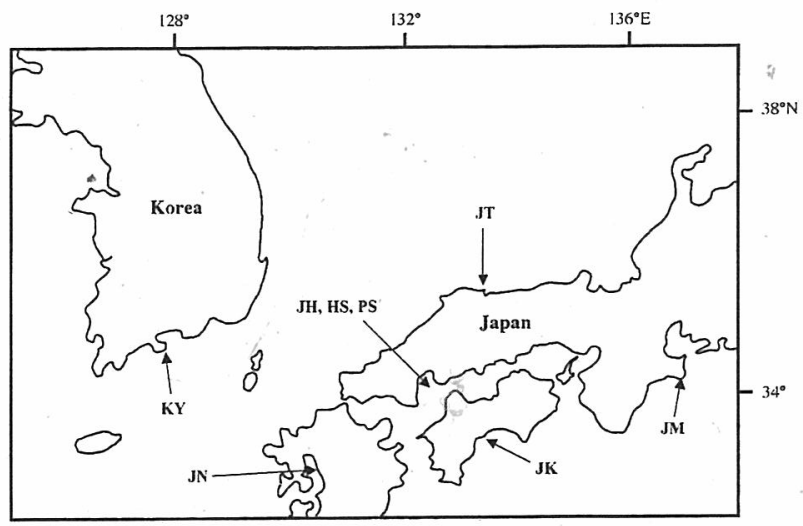

Fig. 1 Map showing sampling locations of black sea bream. KY, Yosu; JH, Hiroshima; HS, hatchery stock; PS, post stock; JK, Kochi; JM; Mie; JN, Nagasaki; JT; Tottori.

extracted DNA were digested with Sau 3AI, and fragments ranging between 400 and $600 \mathrm{bp}$ were selected on agarose gel. The size selected fragments were ligated into the BamHI site of pUC 18 plasmid vector. Positive transformations were screened by the chemiluminescence method with (CA) ${ }_{10}$ synthetic biotinylated oligonucleotide. Positive clones were sequenced using $\mathrm{ABI} \mathrm{PRISM}^{\mathrm{TM}}$ 373 A sequencer (PE Applied Biosystems, Japan). Primer sets of flanking microsatellites were designed using the DNASIS software version 3.2 (Hitachi Engineering, Japan).

In every set of primers, the $5^{\prime}$ end of the reverse primer was labeled with biotin. Polymerase chain reaction (PCR) was carried out in 30 cycles of $1 \mathrm{~min}$ at $94^{\circ} \mathrm{C}$ and $30 \mathrm{~s}$ at the annealing temperature (Table 1), and then extended by $30 \mathrm{~s}$ at $72^{\circ} \mathrm{C}$. Each PCR product $(2-3 \mu \mathrm{L})$ was electrophoresed in $8 \%$ polyacrylamide gel ( $7 \mathrm{M}$ urea, $8 \%$ polyacrylamide). After the run, amplified DNA samples were transferred to the nylon membrane, and then detected by the chemiluminescence method (Sequencing high-Cycle; Toyobo, Japan). The size of the alleles was determined according to pUC18 ssDNA as the sequencer ladder.

Microsatellite loci were tested as to whether they inherit according to Mendelian manner or not. In the present study an inheritance experiment was conducted using a single spawning pair and their progeny, at the Hiroshima City Marine Products Promotion Association.

\section{Data analyses}

Genetic diversity for each location was evaluated by the number of alleles per locus, the observed heterozygosity $\left(\mathrm{H}_{0}\right)$, and the expected heterozygosity $\left(\mathrm{H}_{\mathrm{e}}\right)$. Genotype frequencies at each locus in 
Table 1 Core sequence of microsatellite loci and primers used in the present study

\begin{tabular}{lcccc}
\hline Locus & Core sequence & \multicolumn{1}{c}{ Primer $\left(5^{\prime}-3^{\prime}\right)$} & $\begin{array}{c}\text { Aneal temperature } \\
\left(\mathrm{C}^{\circ}\right)\end{array}$ & $\begin{array}{c}\text { GenBank } \\
\text { number }\end{array}$ \\
\hline Acs 1* & $(\mathrm{CA})_{13}$ & $\begin{array}{l}\text { F: TTGCAGCAGATGGGTTCAGA } \\
\text { R: GGTCATCTGTATCGACGACT }\end{array}$ & 58 & AB102864 \\
Acs3* & $(\mathrm{CA})_{16}$ & $\begin{array}{l}\text { F: GGACCCATATGGCTGTCAAA } \\
\text { R: TTTATGAGCGACCCTGAGTC }\end{array}$ & 57 & AB095008 \\
Acs6* & $(\mathrm{GT})_{12}$ & $\begin{array}{l}\text { F: GTCTGACATCATGCTCTGAG } \\
\text { R: ACAACCGTCTTCTTCTTACG }\end{array}$ & 56 & AB095010 \\
Acs9* & $(\mathrm{CA})_{21}$ & $\begin{array}{l}\text { F: GAACTGACAGTAGTGACTGG } \\
\text { R: GTGCTGCAGTTTATATCTC }\end{array}$ & 56 & AB095011 \\
& & & &
\end{tabular}

F, forward; R, reverse.

Table 2 Results of allelic inheritance in the interbreeding experiment of black sea bream

\begin{tabular}{|c|c|c|c|c|c|c|c|}
\hline \multirow[b]{2}{*}{ Locus } & \multicolumn{2}{|c|}{ Parental genotype } & \multicolumn{4}{|c|}{ Offspring genotype } & \multirow[b]{2}{*}{$\chi^{2}$} \\
\hline & Male & Female & & No. obse & xpected) & & \\
\hline Acs $1^{*}$ & aa & aa & $\begin{array}{l}\text { aa } \\
27(27.0)\end{array}$ & & & & 0.00 \\
\hline Acs3* & $\mathrm{ac}$ & $\mathrm{bb}$ & $\begin{array}{l}\mathrm{ab} \\
13(13.5)\end{array}$ & $\begin{array}{l}\text { bc } \\
14(13.5)\end{array}$ & & & 0.04 \\
\hline $\operatorname{Acs} 6^{*}$ & ac & bd & $\begin{array}{l}\mathrm{ab} \\
7(6.75)\end{array}$ & $\begin{array}{l}\text { bd } \\
8(6.75)\end{array}$ & $\begin{array}{l}\text { ac } \\
7(6.75)\end{array}$ & $\begin{array}{l}\mathrm{cd} \\
5(6.75)\end{array}$ & 0.70 \\
\hline $\operatorname{Acs} 9 *$ & ac & bd & ab $7(6.75)$ & $\begin{array}{l}\text { ad } \\
8(6.75)\end{array}$ & $\begin{array}{l}\text { bc } \\
6(6.75)\end{array}$ & $\begin{array}{l}\text { cd } \\
6(6.75)\end{array}$ & 0.41 \\
\hline
\end{tabular}

each population were tested for conformity to Hardy-Weinberg equilibrium following a Markov chain method. The significance of pairwise Wright's $F_{S T}$ for population genetic difference was tested using AREQUIN version 1.1. ${ }^{16}$ The PHYLIP version 3.5 software $^{17}$ was used for bootstrapping, genetic distance estimation and dendrogram construction. Allele frequencies were bootstrapped 1000 times by the PHYLIP program. An unweighted pair group method with arithmetic average (UPGMA) dendrogram was visualized with the TREEVIEW program. ${ }^{18}$

\section{RESULTS}

Four isolated microsatelitte loci and developed primers set for PCR amplification in black sea bream are shown in Table 1. Inheritance of each microsatellite locus was examined using the single spawning pair and genotypic segregations at the four loci are shown in Table 2. The AcsI* loci was monomorphic because of only one genotype. The Acs 3*, Acs 4* and Acs 9* loci were polymorphic. Isolated microsatellite in the present study exhibited Mendelian manner of inheritance.

Genetic variations at four microsatellite loci examined in the eight populations are summarized in Table 3. The number of alleles at each loci ranged from 6 to 21. Acs9* was particularly diverse with 16-21 alleles. The mean number of alleles per locus in the wild populations ranged from 10.8 to 13.5 and was higher than that of the hatchery stock population at 10.0. The mean $\mathrm{H}_{\mathrm{o}}$ and $\mathrm{H}_{\mathrm{e}}$ ranged from 0.751 to 0.842 and $0.774-0.826$, respectively. The $\mathrm{H}_{\mathrm{o}}$ of the Tottori population (at 0.751 ) and Kochi populations (at 0.755 ) were low among the eight populations. For mean $\mathrm{H}_{e}$, the Kochi populations had the lowest value. Low levels of $\mathrm{H}_{\mathrm{o}} / \mathrm{H}_{\mathrm{e}}$ were detected at the Acs $1^{*}$ loci in the Kochi and Tottori populations.

A deviation from Hardy-Weinberg equilibrium (HWE) assessed by the Markov chain procedure $(P<0.05)$ was observed in the Kochi, Tottori, Yosu, Hiroshima and the post-stock population at locus Acs 1*. The deviation was also observed in Hiroshima and Mie populations at locus Acs3*, and in the Mie population at locus Acs9* (Table 3).

Table 4 shows allele frequencies in eight populations. At locus Acsl*, the allele $123 \mathrm{bp}$ exhibited high frequencies ranging from 0.460 to 0.628 among the western Japan populations, while Yosu population was 0.277 only. Differences can be seen for the major allele $92 \mathrm{bp}$ of locus Acs 3 between both Nagasaki and Kochi 
Table 3 Genetic variability of four microsatellite loci in eight populations of black sea bream

\begin{tabular}{|c|c|c|c|c|c|}
\hline Populations & $A c s 1^{*}$ & Acs3* & $\operatorname{Acs} 4^{*}$ & $\operatorname{Acs} 9 *$ & Mean $^{\prime}$ \\
\hline \multicolumn{6}{|l|}{ Kochi } \\
\hline No. samples & 50 & 50 & 50 & 50 & \\
\hline No. alleles & 6 & 14 & 7 & 16 & 10.8 \\
\hline Heterozygosity $\left(\mathrm{H}_{\mathrm{o}}\right)$ & 0.580 & 0.800 & 0.740 & 0.900 & 0.755 \\
\hline$\left(\mathrm{H}_{\mathrm{e}}\right)$ & 0.706 & 0.783 & 0.702 & 0.905 & 0.774 \\
\hline$\left(\mathrm{H}_{0} / \mathrm{H}_{\mathrm{e}}\right)$ & $0.822^{* *}$ & 1.022 & 1.054 & 0.994 & 0.975 \\
\hline \multicolumn{6}{|l|}{ Mie } \\
\hline No. samples & 50 & 47 & 50 & 50 & \\
\hline No. alleles & 8 & 13 & 9 & 21 & 12.8 \\
\hline Heterozygosity $\left(\mathrm{H}_{\mathrm{o}}\right)$ & 0.660 & 0.808 & 0.820 & 0.880 & 0.792 \\
\hline$\left(\mathrm{H}_{\mathrm{e}}\right)$ & 0.689 & 0.802 & 0.795 & 0.929 & 0.804 \\
\hline$\left(\mathrm{H}_{\mathrm{o}} / \mathrm{H}_{\mathrm{e}}\right)$ & 0.958 & $1.007^{* *}$ & 1.031 & 0.947 & $0.986^{* *}$ \\
\hline \multicolumn{6}{|l|}{ Nagasaki } \\
\hline No. samples & 27 & 26 & 26 & 26 & 13.0 \\
\hline No. alleles & 8 & 18 & 7 & 19 & 0.820 \\
\hline Heterozygosity $\left(\mathrm{H}_{\mathrm{o}}\right)$ & 0.704 & 0.846 & 0.846 & 0.885 & 0.826 \\
\hline$\left(\mathrm{H}_{\mathrm{e}}\right)$ & 0.680 & 0.905 & 0.791 & 0.930 & 0.993 \\
\hline$\left(\mathrm{H}_{0} / \mathrm{H}_{\mathrm{e}}\right)$ & 1.035 & 0.935 & 1.070 & 0.952 & \\
\hline \multicolumn{6}{|l|}{ Tottori } \\
\hline No. sampleś & 47 & 46 & 49 & 49 & 13.5 \\
\hline No. alleles & 10 & 18 & 8 & 18 & 0.751 \\
\hline Heterozygosity $\left(\mathrm{H}_{o}\right)$ & 0.553 & 0.783 & 0.775 & 0.894 & 0.818 \\
\hline$\left(\mathrm{H}_{\mathrm{e}}\right)$ & 0.701 & 0.870 & 0.784 & 0.919 & 0.918 \\
\hline$\left(\mathrm{H}_{0} / \mathrm{H}_{\mathrm{e}}\right)$ & $0.789^{* *}$ & 0.900 & 0.989 & 0.973 & \\
\hline \multicolumn{6}{|l|}{ Yosu (Korea) } \\
\hline No. samples & 47 & 48 & 50 & 50 & 12.8 \\
\hline No. alleles & 10 & 14 & 8 & 19 & 0.818 \\
\hline Heterozygosity $\left(\mathrm{H}_{0}\right)$ & 0.681 & 0.792 & 0.800 & 1.000 & 0.816 \\
\hline$\left(\mathrm{H}_{\mathrm{e}}\right)$ & 0.748 & 0.807 & 0.791 & 0.919 & 1.002 \\
\hline$\left(\mathrm{H}_{0} / \mathrm{H}_{\mathrm{e}}\right)$ & $0.910^{* *}$ & 0.981 & 1.011 & 1.088 & \\
\hline \multicolumn{6}{|l|}{ Hiroshima } \\
\hline No. samples & 46 & 47 & 48 & 47 & \\
\hline No. alleles & 6 & 15 & 6 & 20 & 11.8 \\
\hline Heterozygosity $\left(\mathrm{H}_{0}\right)$ & 0.652 & 0.808 & 0.896 & 0.957 & 0.828 \\
\hline$\left(\mathrm{H}_{\mathrm{e}}\right)$ & 0.627 & 0.821 & 0.774 & 0.916 & 0.784 \\
\hline$\left(\mathrm{H}_{\mathrm{o}} / \mathrm{H}_{\mathrm{e}}\right)$ & $1.040^{* *}$ & $0.984^{* *}$ & 1.158 & 1.045 & 1.056 \\
\hline \multicolumn{6}{|c|}{ Hatchery stock in Hiroshima } \\
\hline No. samples & 47 & 42 & 47 & 49 & \\
\hline No. alleles & 6 & 10 & 8 & 16 & 10.0 \\
\hline Heterozygosity $\left(\mathrm{H}_{\mathrm{o}}\right)$ & 0.574 & 0.881 & 0.915 & 1.000 & 0.842 \\
\hline$\left(\mathrm{H}_{\mathrm{e}}\right)$ & 0.547 & 0.812 & 0.838 & 0.909 & 0.776 \\
\hline$\left(\mathrm{H}_{\mathrm{o}} / \mathrm{H}_{\mathrm{e}}\right)$ & . 1.049 & 1.085 & 1.092 & 1.100 & 1.085 \\
\hline \multicolumn{6}{|l|}{ Post-stock in Hiroshima } \\
\hline No. samples & 48 & 42 & 49 & 45 & \\
\hline No. alleles & 8 & 13 & 7 & 17 & 11.2 \\
\hline Heterozygosity $\left(\mathrm{H}_{\mathrm{o}}\right)$ & 0.521 & 0.905 & 0.857 & 1.000 & 0.821 \\
\hline$\left(\mathrm{H}_{\mathrm{e}}\right)$ & 0.591 & 0.822 & 0.802 & 0.887 & 0.775 \\
\hline$\left(\mathrm{H}_{\mathrm{o}} / \mathrm{H}_{\mathrm{e}}\right)$ & $0.882^{* *}$ & 1.101 & 1.069 & 1.127 & 1.045 \\
\hline
\end{tabular}

$\mathrm{H}_{\mathrm{o}}$, observed; $\mathrm{H}_{\mathrm{e}}$, expected.

** Departure from Hardy-Weinberg equilibrium by Markov chain procedure $(P<0.05)$.

populations, and other populations. The major allele of the Acs $4^{*}$ locus in Kochi population was $71 \mathrm{bp}$ while that of other populations was $69 \mathrm{bp}$. The allele $85 \mathrm{bp}$ and $97 \mathrm{bp}$ at $\operatorname{Acs} 9 *$ locus in Kochi population was different from other populations.
The pairwise $F_{S T}$ test showed that the Kochi population was significantly different $(P<0.05)$ from all the other populations except for the Hiroshima population. Difference between the Nagasaki and Yosu population was also evident (Table 5). 
Table 4 Allele frequencies in eight populations of black sea bream

\begin{tabular}{|c|c|c|c|c|c|c|c|c|}
\hline Allele (bp) & Kochi & Mie & Nagasaki & Tottori & Yosu & Hiroshima & Hatchery stock & Post stock \\
\hline \multicolumn{9}{|l|}{$\overline{A c s 1^{*}}$} \\
\hline $109-119$ & 0.100 & 0.080 & 0.000 & 0.022 & 0.032 & 0.000 & 0.011 & 0.031 \\
\hline 121 & 0.080 & 0.290 & 0.148 & 0.128 & 0.074 & 0.130 & 0.223 & 0.167 \\
\hline 123 & 0.480 & 0.460 & 0.498 & 0.467 & 0.277 & 0.566 & 0.628 & 0.604 \\
\hline 125 & 0.180 & 0.040 & 0.074 & 0.234 & 0.382 & 0.087 & 0.053 & 0.104 \\
\hline 127 & 0.050 & 0.100 & 0.204 & 0.085 & 0.096 & 0.163 & 0.074 & 0.063 \\
\hline 129 & 0.000 & 0.000 & 0.019 & 0.021 & 0.117 & 0.000 & 0.000 & 0.021 \\
\hline $131-137$ & 0.110 & 0.030 & 0.057 & 0.043 & 0.022 & 0.054 & 0.011 & 0.010 \\
\hline \multicolumn{9}{|l|}{ Acs $3^{*}$} \\
\hline $74-88$ & 0.010 & 0.000 & 0.096 & 0.076 & 0.021 & 0.011 & 0.000 & 0.000 \\
\hline 90 & 0.090 & 0.074 & 0.193 & 0.130 & 0.156 & 0.160 & 0.107 & 0.107 \\
\hline 92 & 0.420 & 0.340 & 0.058 & 0.283 & 0.344 & 0.351 , & 0.345 & 0.357 \\
\hline 94 & 0.060 & 0.191 & 0.019 & 0.043 & 0.198 & 0.096 & 0.155 & 0.143 \\
\hline 96 & 0.110 & 0.149 & 0.135 & 0.098 & 0.052 & 0.085 & 0.083 & 0.036 \\
\hline $98-128$ & 0.200 & 0.235 & 0.346 & 0.218 & 0.155 & 0.244 & 0.227 & 0.204 \\
\hline \multicolumn{9}{|l|}{$A c s 4^{*}$} \\
\hline $59-65$ & 0.040 & 0.120 & 0.058 & 0.154 & 0.060 & 0.042 & 0.191 & 0.133 \\
\hline 67 & 0.070 & 0.100 & 0.096 & 0.214 & 0.080 & 0.104 & 0.191 & 0.133 \\
\hline 69 & 0.220 & 0.340 & 0.135 & 0.326 & 0.280 & 0.219 & 0.160 & 0.214 \\
\hline 71 & 0.470 & 0.190 & 0.308 & 0.214 & 0.220 & 0.312 & 0.245 & 0.133 \\
\hline 73 & 0.140 & 0.190 & 0.269 & 0.082 & 0.260 & 0.250 & 0.149 & 0.316 \\
\hline $75-77$ & 0.060 & 0.060 & 0.134 & 0.010 & 0.100 & 0.073 & 0.064 & 0.071 \\
\hline \multicolumn{9}{|l|}{$\operatorname{Acs} 9^{*}$} \\
\hline $71-81$ & 0.180 & 0.270 & 0.212 & 0.347 & 0.230 & 0.180 & 0.101 & 0.145 \\
\hline 83 & 0.130 & 0.100 & 0.058 & 0.071 & 0.140 & 0.074 & 0.082 & 0.033 \\
\hline 85 & 0.170 & 0.050 & 0.038 & 0.071 & 0.080 & 0.117 & 0.133 & 0.067 \\
\hline 87 & 0.060 & 0.080 & 0.077 & 0.153 & 0.120 & 0.021 & 0.071 & 0.056 \\
\hline 89 & 0.000 & 0.080 & 0.135 & 0.092 & 0.080 & 0.160 & 0.133 & 0.256 \\
\hline 91 & 0.010 & 0.040 & 0.077 & 0.092 & 0.070 & 0.117 & 0.133 & 0.133 \\
\hline 93-119 & 0.450 & 0.380 & 0.403 & 0.174 & 0.280 & 0.331 & 0.347 & 0.310 \\
\hline
\end{tabular}

Table 5 Pairwise comparison of $F_{S T}$ in eight populations of black sea bream

\begin{tabular}{|c|c|c|c|c|c|c|c|}
\hline Populations & Kochi & Mie & Nagasaki & Tottori & Yosu & Hiroshima & $\begin{array}{c}\text { Hatchery } \\
\text { stock }\end{array}$ \\
\hline \multicolumn{8}{|l|}{ Kochi } \\
\hline Mie & $0.0325^{* *}$ & & & & & & \\
\hline Nagasaki & $0.0259 * *$ & 0.0158 & & & & & \\
\hline Tottori & $0.0370^{* *}$ & -0.0006 & 0.0285 & & & & \\
\hline Yosu & $0.0274^{* *}$ & 0.0001 & $0.0022^{* *}$ & 0.0085 & & & \\
\hline Hiroshima & 0.0227 & 0.0127 & -0.0011 & 0.0242 & 0.0036 & & \\
\hline Hatchery stock & $0.0371^{* *}$ & 0.0199 & 0.0077 & 0.0136 & 0.0127 & 0.0034 & \\
\hline Post stock & $0.0720^{* *}$ & 0.0216 & 0.0085 & 0.0386 & 0.0139 & 0.0098 & 0.0148 \\
\hline
\end{tabular}

**Significance level at $P<0.05$.

A UPGMA dendrogram based on Nei's genetic distance is shown in Fig. 2. No geographic relationship and genetically differentiated populations were found in the western Japan populations. However, slight genetic divergence was found between the Yosu and the western Japan populations. The hatchery stock and post-stock population exhibited little genetic distance from the wild Hiroshima population.

\section{DISCUSSION}

Microsatellites DNA markers are more polymorphic than isozymes in the analysis of genetic diversity. For example, in analysis of wild and hatchery-reared black sea bream with 42 isozyme loci, the number of alleles per locus ranged from 1.095 to 1.35 and the $\mathrm{H}_{0}$ ranged from 0.048 to $0.066 .^{19}$ In contrast, the four microsatellite loci 


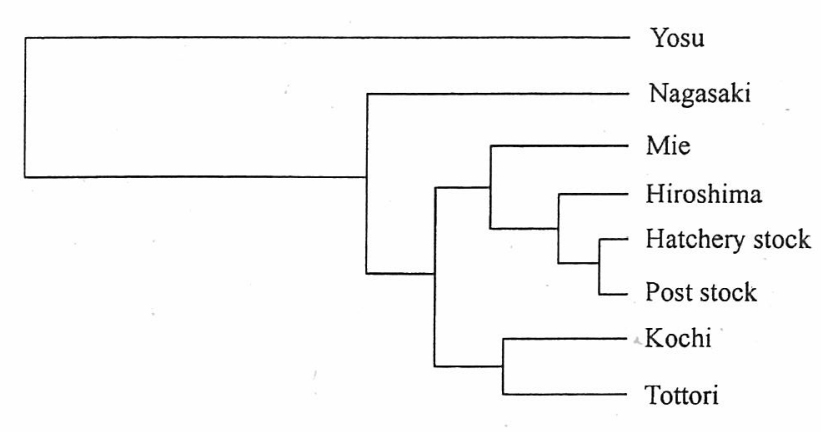

0.1

Fig. 2 UPGMA dendrogram of western Japan and southern Korea based on Nei's genetic distance.

used in the present study had a mean number of alleles per locus ranging from 10.0 to 13.5 and had a $\mathrm{H}_{\mathrm{o}}$ between 0.751 and 0.842 . On the microsatellite performance in black sea bream, the number of alleles per locus was fewer than that observed in red sea bream ${ }^{2}$ and Japanese flounder ${ }^{10}$ but the $\mathrm{H}_{\circ}$ was similar to those reported in the two species.

For the hatchery stock population in Hiroshima Bay, the mean $\mathrm{H}_{0}$ and $\mathrm{H}_{\mathrm{e}}$ were 0.842 and 0.776 , respectively. These values almost coincided with those estimated in wild populations. Based on the $\mathrm{H}_{\mathrm{o}}$ and $\mathrm{H}_{\mathrm{e}}$, hatchery stock population seems to be conserved at a reasonable level of genetic variation. However, the lowest mean number of alleles per locus in hatchery stock population was noted, comparing with those in the wild populations. Therefore, to evaluate genetic diversity using microsatellite, the mean number of alleles per locus is a better indicator than $\mathrm{H}_{0}$ and $\mathrm{H}_{\mathrm{e}}$. The lowest value of the mean number of alleles per locus in hatchery stock population may be accounted for by the small number of broodstock ( $n=51$; composed of 29 female and 22 male fish).

A significant deviation from HWE was observed in some microsatellite loci of the western Japan populations with excess homozygosity. It is suggested that a large number of stocked fish might cause a mixing with indigenous populations and thus each population could include several separately spawning subpopulations. This situation was also suggested in red sea bream. ${ }^{8}$ The explanation of mixing of stocked population with the indigenous population can be partly supported by the Kochi population. Here, $30 \%$ of them had a deformity in the internostril epidermis, which often arises under hatchery-reared conditions. ${ }^{20}$

For genetic divergence in the wild population in western Japan, the significantly different $F_{S T}$ $(P<0.05)$ was detected only for the Kochi population, although the reason is not clear at present. As the mentioned here, it might be caused by a large number of stocking seed with genetic drift. Overall, according to the results of $F_{S T}$ and genetic distance on the dendrogram, black sea bream in western Japan have little geographic divergence. This conclusion is the same as that reported by Taniguchi et al., in which three natural populations were not different by the homogeneity test using 42 isozyme loci. ${ }^{19}$ Kijima and Fujio also pointed out relatively little genetic differentiation in black sea bream among Japanese marine teleosts. ${ }^{21}$ A question arises as to why black sea bream in western Japan could have little geographic divergence. This may be attributed to the randam disperal of pelagic eggs and larvae, and extensive migration habit of the adult fish. The extensive migration of black sea bream was demonstrated by ultrasonic telemetry (Fukuda T, pers. comm., 2000).

The significantly different $F_{S T}$ was seen in the Yosu and Nagasaki populations. Moreover, there was relatively large genetic distance on a dendrogram between Yosu population and the western Japan populations. These results partly support the existence of genetically differentiated populations between western Japan and southern Korea. Further research will be required for better understanding of the genetic structure of the wild population of black sea bream, using a larger number of samples from more sampling locations.

Focusing on the hatchery stock and post-stock populations, there was little increase in mean number of alleles per locus from the hatchery levels and a decrease from wild levels in the poststock population. This can be partly explained by the mixing between the two populations. In fact, according to the mark-tracing experiment at Daio Bay of Nino-shima Island, the mixing rate of hatchery stock seed to the wild reached more than $50 \%$ at 10 days after stocking. ${ }^{13}$ The negligible genetic distance between hatchery stock and post-stock population indicates that microsatellites developed in the present study have strong possibilities as a stock separation tool. From the viewpoint of conservation genetics, it is noteworthy that the little genetic distance between the hatchery stock and the wild Hiroshima population was marked.

\section{ACKNOWLEDGMENTS}

We express special thanks to Hiroshima City Marine Products Promotion Association for providing specimens used in the present study. We wish to thank Dr Motohiro Takagi of Ehime University and Mr Masaya Okabe of Kochi Prefectural Freshwater Fisheries Center for useful comments and technical support. We are grateful to $\mathrm{Mr}$ 
Sherrill-Mix of Hiroshima University, for his critical reading of the manuscript. Thanks are also due to cooperative members for collecting specimens: $\mathrm{Dr}$ Ryo Suzuki for Mie, Mr Hisashi Nakamura for Tottori, MrYukiharu Nakamura for Hiroshima, and Mr Masayuki Takeyama for the Kochi population. The present study was supported in part by a Grant-in-Aid for University and Society from the Ministry of Education, Culture, Sports, Science and Technology of Japan (No.11794009), and Heiwa Nakajima Foundation.

\section{REFERENCES}

1. Perez-Enriquez R, Takagi M, Taniguchi N. Genetic change and pedigrees tracing of a hatchery-reared stocks of red sea bream (Pagrus major) used for stock enhancement, based on microsatellite DNA markers. Aquaculture 1999; 173: 413-423.

2. Perez-Enriquez R, Takemura M, Tabata K, Taniguchi N. Genetic diversity of red sea bream Pagrus major in western Japan in relation to stock enhancement. Fish. Sci. 2001; 67: 71-78.

3. Tessier N, Bernatchez L, Wright JM. Population structure and impact supportive breeding inferred from mitochondrial and microsatellite DNA analyses in land-locked Atlantic salmon Salmo salar L. Mol. Ecol. 1997; 6: 735750.

4. Litt M, Luty JA. A hypervariable microsatellite revealed by in vitro amplification of a dinucleotide repeat within the cardiac muscle actin gene. Am. J. Hum. Genet. 1989; 44: 397-401.

5. Tautz D. Hypervariability of simple sequences as a general source for polymorphic DNA marker. Nucleic Acids Res. 1989; 17: 6463-6471.

6. Takagi M, Shoji E, Taniguchi N. Microsatellite DNA polymorphism to reveal genetic divergence in Ayu, Plecoglossus altivelis. Fish. Sci. 1999; 65: 507-512.

7. Na-Nakon U, Taniguchi N, Nugroho E, Seki S, Kamonrat W. Isolation and characterization of microsatellite loci of Clarias macrocephalus and their application to genetic diversity study. Fish. Sci. 1999; 65: 520-526.

8. Perez-Enriquez R, Taniguchi N. Genetic structure of red sea bream (Pagrus major) population off Japan and the southwest Pacific, using microsatellite DNA markers. Fish. Sci. 1999; 65: 23-30.

9. Nugroho E, Taniguchi N, Kato K, Miyashita S. Genetic dif- ference among seed populations of greater amberjack used in aquaculture farm of Japan. Suisanzoshoku 2000; 48: 665674.

10. Yoshida K, 'Takagi M, Tanaka M, Taniguchi N. Genetic variability and divergence of wild and artificially raised Japanese flounder Paralichthys olivaceus inferred from microsatellite DNA analysis. Fish Genet. Breed Sci. 2000; 29: 93-102.

11. McConnell SK, OíReilly P, Hamilton L, Wright J, Bentzen P. Polymorphic microsatellite loci from Atlantic salmon (Salmo salar): genetic differentiation of North American and European populations. Can. J. Fish. Aquat. Sci. 1995; 52: $1863-1872$.

12. Takagi M, Mikita $K$, Taniguchi N. Genetic change in the hatchery stock fior release and net-cage culture of red sea bream (Pagrus major) using microsatellite markers. J. Anim. Genet. 1996; 24: 53-58.

13. Umino T, Hayashi M, Miyatake J, Nakayama K, Sasaki T, Okada K, Nakagawa H. Significance of release of black sea bream at 20-mm size on stock enhancement in Daio Bay, Hiroshima. Suisanzoshoku 1999; 47: 337-342.

14. Nakagawa $H$, Unimo $T$, Hayashi $M$, Sasaki T, Okada $K$. Changes in biochemical composition of black sea bream released at $20 \mathrm{~mm}$ size in Daio Bay, Hiroshima. Suisanzoshoku 2000; 48: 643-648.

15. Yamashida H, Unimo T, Nakahara S, Okada K, Nakagawa H. Comparison of biochemical characteristics between hatchery-produced and wild black sea bream. Nippon Suisan Gakkaishi 1996; 62: 89-93.

16. Schneider S, Kueffer JK, Roessli D, Excoffier L. arequin, Version 1.1: Software for Population Genetic Data Analysis. Genetics and Biometry Laboratory, University of Geneva, Geneva. 1997.

17. Felsenstein J. phylip (Phylogeny Inference Package, Version 3.5. Department of Genetics, University of Washington, Seattle. 1993.

18. Page RDM. TREEVIEW. An application to display phylogenetic trees on personal computers. Comp. Appl. Biosci. 1996; 12: 357-358.

19. Taniguchi N, Sumantadinata K, Iyama S. Genetic change in the first and second generations of hatchery stock of black sea bream. Aquaculture 1983; 35: 309-320.

20. Matsuoka M. On the deformity of the inter-nostril epidermis in the black sea bream. Suisanzoshoku 2000; 48: 675676.

21. Kijima A, Fujio Y. Genetic analysis of population structure in marine teleosts around Japan. In: Ogita Z, Market CL (eds). Isozymes: Structure, Function, and Use in Biology and Medicine. Wiley-Liss, New York. 1990; 117-206. 